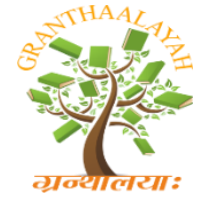

INTERNATIONAL JOURNAL OF RESEARCH GRANTHAALAYAH A knowledge Repository

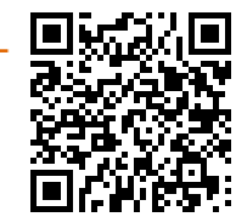

RAST - 17

\title{
COMPARATIVE STUDY OF MARINE ALGAE ISOLATED FROM EAST COAST OF INDIA BY REDUCING POWER ASSAY
}

\author{
Leelavathi M $\mathrm{S}^{* 1}$, Prasad M $\mathbf{P}^{2}$ \\ ${ }^{* 1}$ Research Scholar, Bharathiar University, Coimbatore, India \\ ${ }^{* 1}$ Faculty, VidyaSoudha PU College, Peenya, Bangalore, India \\ ${ }^{2}$ Prasad M P, Senior Scientist, Sangenomics Research Labs, Bangalore, India
}

DOI: https://doi.org/10.29121/granthaalayah.v5.i4RAST.2017.3306

\begin{abstract}
The Gulf of Mannar is a Marine Biosphere Reserve situated along the east coast of India and Sri Lanka, an area of about 10,500 sq. $\mathrm{km}$ which has a luxuriant growth of about 680 species of seaweed belonging to the Rhodophyta, Pheaophyta and Chlorophyta, in both the inter-tidal and deep water regions. Seaweed constitutes a commercially important marine renewable resource. Seaweeds are rich in polysaccharides, minerals, proteins and vitamins. Documented antioxidant activity would elevate their value in the human diet as food and pharmaceutical supplements thus, in the present investigation the sea weed samples were collected in sterile condition and their antioxidant property for methanolic and petroleum ether extract was carried out by reducing power assay. The extraction process was carried out by drying and extracted the fine powder with different solvents. The extracted samples were then dissolved to a stock concentration of $1 \mathrm{mg} / \mathrm{ml}$ and the reducing power assay was carried out with different concentrations of the sample. The methanolic extract of Cymodoceaeserrulata, Gracillariafolifera and Turbinariaconoides showed higher reducing power when compared to the standard. The petroleum ether extract of Cymodoceaerotundata and Ulvareticulata extracts showed higher activity when compared to the standard whereas Kappaphycussps showed the least activity when checked for its reducing power activity.
\end{abstract}

Keywords: Reducing Power Assay; Antioxidant; Gracillaria Species; Cymodeacea Species; Ulvalactuca.

Cite This Article: Leelavathi M S, and Prasad M P. (2017). "COMPARATIVE STUDY OF MARINE ALGAE ISOLATED FROM EAST COAST OF INDIA BY REDUCING POWER ASSAY." International Journal of Research - Granthaalayah, 5(4) RAST, 73-79. https://doi.org/10.29121/granthaalayah.v5.i4RAST.2017.3306. 
[Leelavathi et. al., Vol.5 (Iss.4: RAST), April, 2017]

ICV (Index Copernicus Value) 2015: 71.21

Recent Advances in Science \& Technology
ISSN- 2350-0530(O), ISSN- 2394-3629(P)

IF: 4.321 (CosmosImpactFactor), 2.532 (I2OR)

InfoBase Index IBI Factor 3.86

\section{Introduction}

Free radicals are responsible for aging and causing various human diseases. A study shows that antioxidant substances which scavenge free radicals play an important role in the prevention of free radical-induced diseases. By donating hydrogen radicals, the primary radicals are reduced to nonradical chemical compounds and are then converted to oxidize antioxidant radicals (Jadhavet al., 1995; Yamaguchi et al., 1998). This action helps in protecting the body from degenerative diseases. Natural antioxidants are not limited to terrestrial sources and reports have revealed seaweeds to be rich sources of natural antioxidant compounds (Lim et al., 2002; Duanet al., 2006; Kudaet al., 2007).

Seaweeds belong to a group of plants known as algae. They are rich in polysaccharides, minerals, proteins and vitamins. They have been classified as Rhodophyta (red algae), Phaeophyta (brown algae) or Chlorophyta (green algae) depending on their nutrient and chemical composition. Like other plants, seaweeds contain various inorganic and organic substances which can benefit human health (Kudaet al., 2002). The estimated range of seaweeds is probably around 45,000 species (Bequette\& France, 1997). Most seaweeds are divided into three categories based on their colours such as red (4,500 species), green (900 species) and brown (1,000 species). It has been used as food, fertilizer and for medicinal purposes for a long time.

Documented antioxidant activity would elevate their value in the human diet as food and pharmaceutical supplements (Yan, Nagata, \& Fan, 1998). Few reports are available on the antioxidant potential of seaweeds (Jimenez-Escriget al., 2001). Ismail and Hong (2002) reported antioxidant activity of four commercial edible seaweeds, namely Nori (Porphyra sp.), Kumbu (Laminaria sp.), Wakame (Undaria sp.) and Hijiki (Hijikia sp.).

Seaweeds have become a major food ingredient in products especially in Japan, Korea and China. Boukhari\& Sophie (1998) reported that most Europeans and Americans use processed seaweeds as additives in their food preparation. In Asia, seaweeds have been used for centuries in the preparation of salads, soups and also as low-calorie foods (Jiménez-Escrig\& SánchezMuniz, 2000). Although most Malaysians exhibit little interest in consuming seaweeds, it is consumed by small pockets of the population along the coastal areas of Peninsular Malaysia and East Malaysia (Norziah\&Ching, 2000).

\section{Materials and Methodology}

The samples were collected a depth of 5-10m by SCUBA diving at Mantapam to Kanyakumari South coast of India and placed inside sterile ethyl polythene bags underwater and transferred to the lab aseptically in iceboxes. The sea weed samples were washed with tap water several times and were authenticated by J. R. Ramalingam, Former technical officer, MantapamRegional center of central Marine Fisheries Research Institute, Tamil Nadu, India as Gracillariacrassa, Gracillariaedulis, Cymodoceaerotundata, Cymodoceaeserrulata, Ulvalactuca, Ulvareticulata, Gracillariafoliifera, Gelidiellaaccrosa,Turbinariaconoides, Kappaphycusalvarezii and Acanthoporaspicifera. The sea weed samples were washed with tap water several times and shade dried, powdered with a blender and stored in an air tight container and kept in a room temperature for further study. 
[Leelavathi et. al., Vol.5 (Iss.4: RAST), April, 2017]

ICV (Index Copernicus Value) 2015: 71.21

Recent Advances in Science \& Technology
ISSN- 2350-0530(O), ISSN- 2394-3629(P)

IF : 4.321 (CosmosImpactFactor), 2.532 (I2OR)

InfoBase Index IBI Factor 3.86

\section{Solvent extraction:}

$5 \mathrm{gm}$ of each sea weed sample powder was added to $50 \mathrm{ml}$ of methanol and petroleum ether solvent separately and kept for $48 \mathrm{hrs}$ with slight shaking condition. Here, methanol and petroleum ether was used as a solvent. After $48 \mathrm{hrs}$, the extract was filtered by using whattmann no1 filter paper. The filtrate collected was evaporated so remove all the solvent present and to obtain a dry powder. The evaporation process was carried out by placing the filtrate in water bath at the boiling temperature of the solvent until the solvent is completely evaporated. The powder was then redissolved in solvents to get a final concentration of $1 \mathrm{mg} / \mathrm{ml}$. These stocks extracts were refrigerated until further use.

\section{Reducing power assay:}

$1 \mathrm{ml}$ of different concentration $(200-1000 \mu \mathrm{g} / \mathrm{ml})$ of sample was mixed with $1.25 \mathrm{ml}$ of potassiumferricyanide $\left(1 \%\right.$, w/v), and incubated at $50^{\circ} \mathrm{C}$ for $30 \mathrm{~min}$. Afterwards, $1.25 \mathrm{ml}$ of TCA $(10 \%, \mathrm{w} / \mathrm{v})$ was added to the mixture to terminate the reaction. Allow the mixture to settle down and leave the residues. About $1 \mathrm{ml}$ of supernatant was diluted with $1 \mathrm{ml}$ of methanol, then the solution was mixed with $0.5 \mathrm{ml}$ ferric chloride $(0.1 \%, \mathrm{w} / \mathrm{v})$ and the absorbance was measured at $700 \mathrm{~nm}$. All tests were performed in triplicate. Graph was plotted with the average of three determinations. L- Ascorbic acid was taken as a standard antioxidant.

\section{Results}

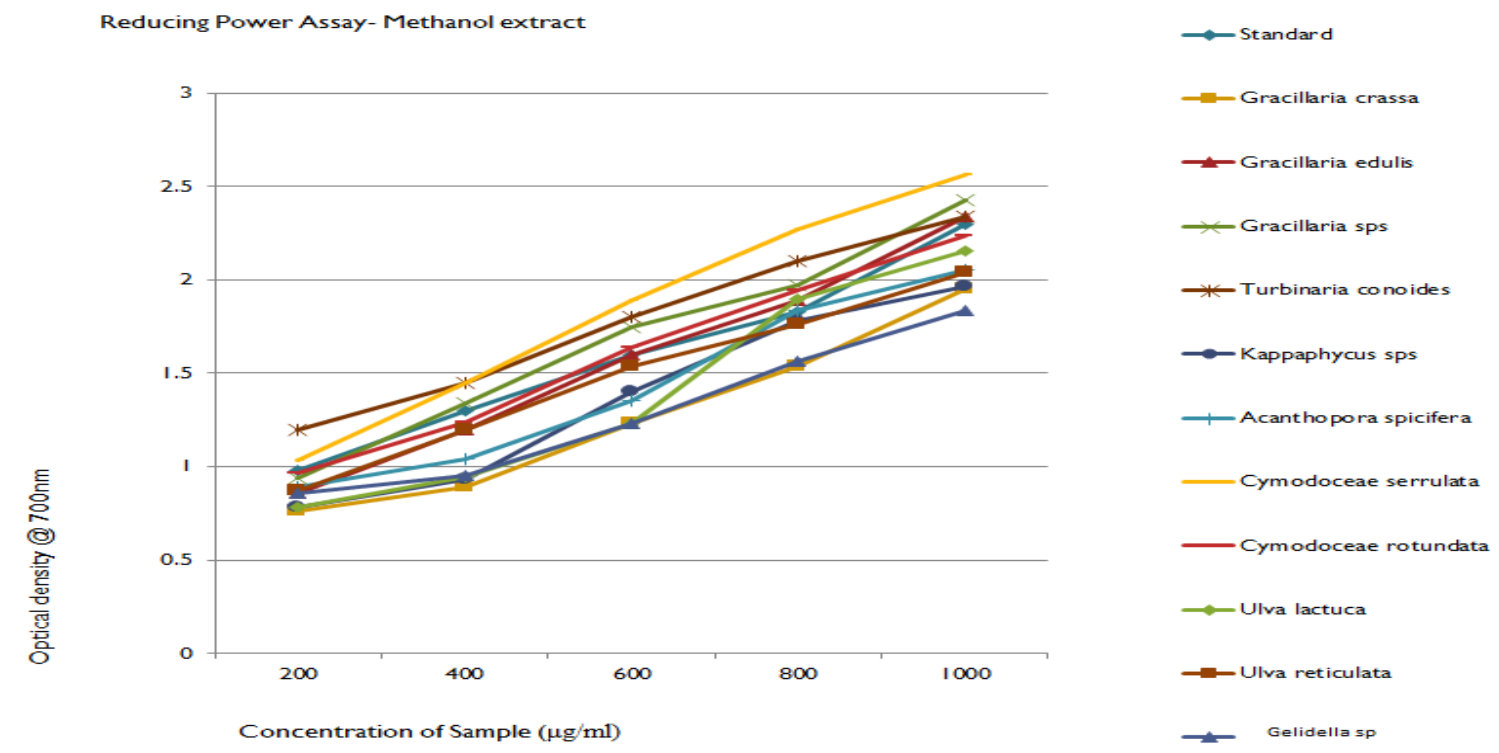

Figure 1: Reducing Power Assay for the methanolic extract of sea weeds.

The reducing power activity for the methanolic extracts was determined and compared with standard ascorbic acid. Cymodoceaeserrulata, Gracillariafolifera and Turbinariaconoides showed higher reducing power when compared to the standard. The activity was determined by using the optical density value at 700nm. The other samples showed similar kind of reducing power activity and were below the standard. Geliedella spshowed the least reducing power activity (Figure 1). 


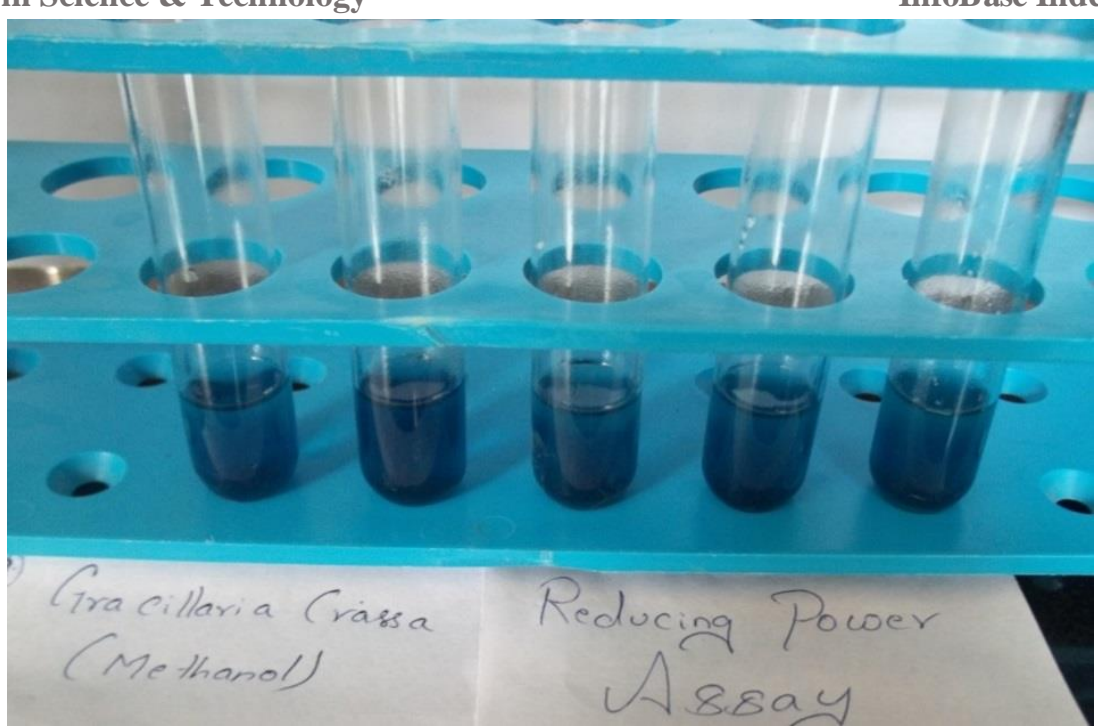

Figure 2: Reducing Power Assay for the methanolic extract of Gracillariacrassa.
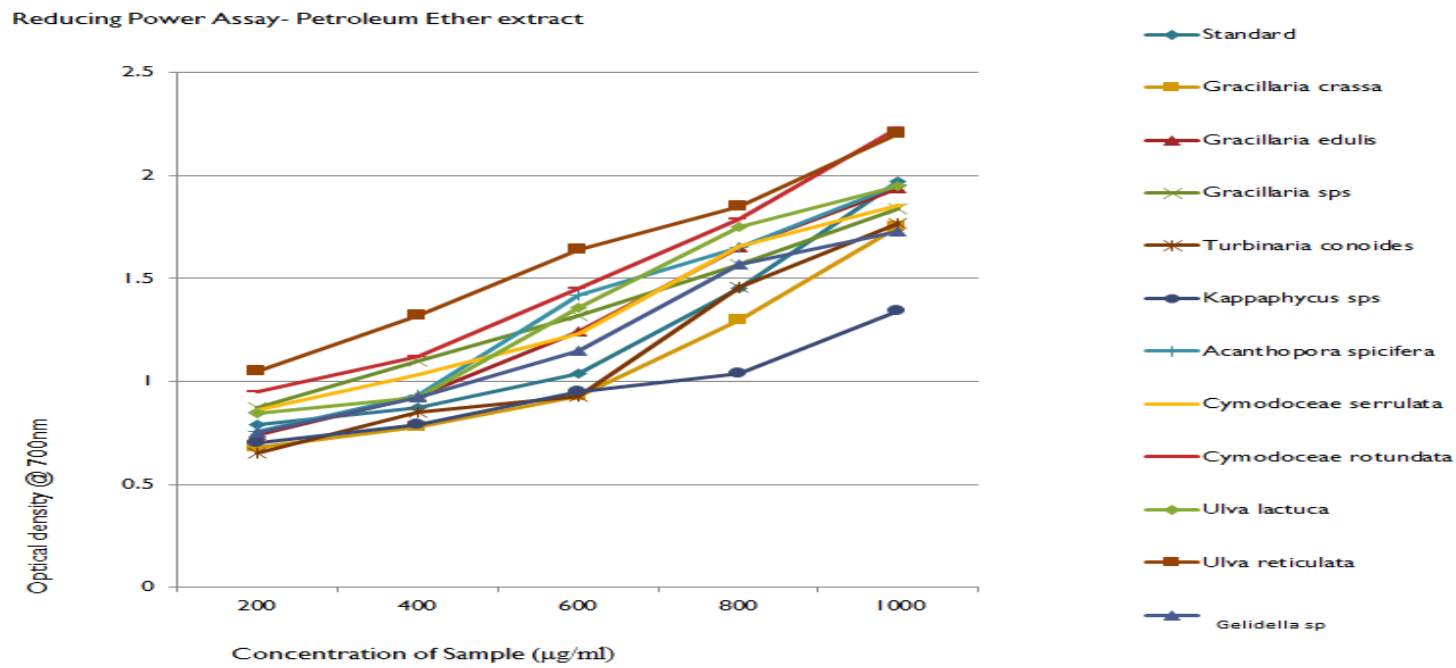

Figure 3: Reducing Power Assay for the Petroleum Ether extract of sea weeds.

The reducing power assay was carried out to determine the reducing power capacity of the petroleum ether extract of the samples in different concentration. The activity of the extracts increased with the increase in the concentration of the samples. The Cymodoceaerotundata and Ulvareticulata extracts showed higher activity when compared to the standard. The petroleum ether extract of Kapppaphycussps. showed the least activity when checked for its reducing power activity (Figure 3 ). 


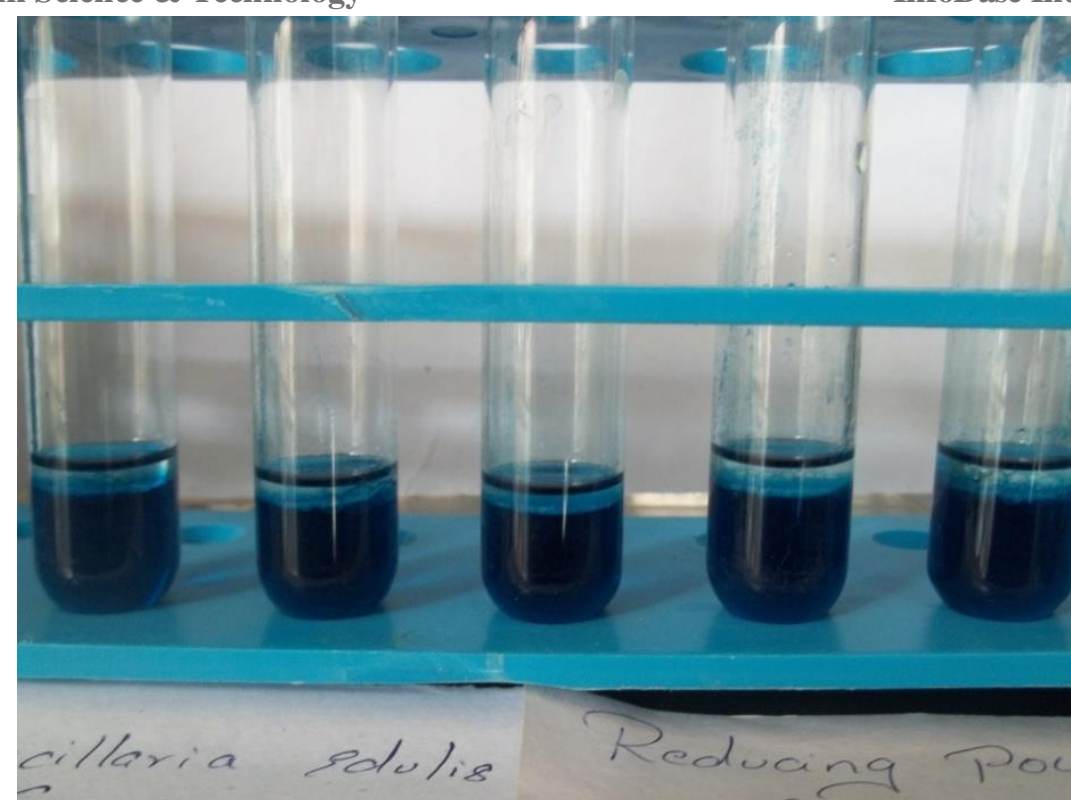

Figure 4: Reducing Power Assay for the Petroleum Ether extract of Gracillariaedulis.

\section{Discussion}

Seaweeds are considered as a source of bioactive compounds as they are able to produce a great variety of secondary metabolites characterized by a broad spectrum of biological activities. Compounds with antioxidant, antiviral, antifungal and antimicrobial activities have been detected in brown, red and green algae (Yuan et al., 2005; Bansemiret al., 2006; Chew et al., 2008).

Sargassum species might be a valuable source of natural antioxidants containing both water-and fatsoluble antioxidative components, preventing oxidative damage of food oils (Siriwardhanaet al. 2003, 2004). Further antioxidative effects of compounds from macroalgae with potential in applications in human health and nutrition are described by Cornish and Garbary (2010).

Le Tutouret al. (1998) demonstrated the ability of several brown seaweed extracts to scavenge peroxyl radicals. Ruperézet al. 2002 demonstrated that fucoidan from Fucusvesiculosus had the highest antioxidant activity in relation to the other fractions, with high levels of uronic acid. Several studies were subsequently performed to verify the antioxidant properties of algae (Zhang et al. 2003; Yuan et al. 2005). Recently, the antioxidant activity of polysaccharides from the chlorophyteUlvapertusa, was also investigated. All of the compounds analyzed showed that molecular weight (MW) had a significant effect on antioxidant activity (Qi et al., 2005).

Brown algae such as Sargassumkjellmanianum(Yan et al., 1996; Yan et al., 1997; Wei \&Xu, 2003), Eiseniabicyclis(Nakmuraet al., 1996), Cystoseira sp. (Chkhikvishvili\&Ramazanov, 2000), Fucus sp. (Jimenez-Escriget al., 2001), and Eckloniastolonifera (Kang et al., 2003a, 2004) have been reported with respect to free radical scavenging and the inhibition of total reactive oxygen species generation by phlorotannin compounds. 
[Leelavathi et. al., Vol.5 (Iss.4: RAST), April, 2017]

ICV (Index Copernicus Value) 2015: 71.21

Recent Advances in Science \& Technology
ISSN- 2350-0530(O), ISSN- 2394-3629(P)

IF : 4.321 (CosmosImpactFactor), 2.532 (I2OR)

InfoBase Index IBI Factor 3.86

\section{Conclusion}

The Seaweeds are natural bioactive compounds which are used in Neutraceuticalswhich have chemical constituents of high therapeutic efficacy. Further studies are required to investigate the marine algae for potential pharmacological properties. The present study suggests that the seaweed extracts possessed antioxidant activity, promising a future scope for the use of marine seaweeds.

\section{References}

[1] Jadhav SJ, Nimbalkar SS, Kulkarni AD \&Madhavi DL. (1995). "LIPID OXIDATION IN BIOLOGICAL AND FOOD SYSTEMS. IN: FOOD ANTIOXIDANTS.”Madhavi DL, Deshpande SS \&Salunkhe DK (edition). New York.

[2] Yamaguchi T, Takamura H, Matoba T \&Terao J (1998). "HPLC METHOD FOR EVALUATION OF THE FREE RADICAL-SCAVENGING ACTIVITY OF FOODS BY USING 1, 1-DIPHENYL-2PICRYLHYDRAZYL.” BiosciBiotechnolBiochem,62: 1201-1204.

[3] Lim, S. N., Cheung, P. C. K., Ooi, V. E. C. and Ang, P. O. (2002)“EVALUATION OF ANTIOXIDATIVE ACTIVITY OF EXTRACTS FROM A BROWN SEAWEED, SARGASSUM SILIQUASTRUM." Journal of Agricultural and Food Chemistry 50: 3862- 3866.

[4] Duan, X. J., Zhang, W. W, Li, X. M. and Wang, B. G. (2006)“EVALUATION OF ANTIOXIDANT PROPERTY OF EXTRACT AND FRACTIONS OBTAINED FROM A RED ALGA, POLYSIPHONIAURCEOLATA." Food Chemistry 95: 37-43.

[5] Kuda, T., Kunii, T., Goto, H., Suzuki, T. and Yano, T. (2007)"VARIETIES OF ANTIOXIDANT AND ANTIBACTERIAL PROPERTIES OF ECKLONIA STOLONIFERA AND ECKLONIA KUROME PRODUCTS HARVESTED AND PROCESSED IN THE NOTO PENINSULA, JAPAN. FOOD CHEMISTRY". 103: 900-905.

[6] Kuda, T., Taniguchi, E., Nishizawa, M. and Araki, Y. (2002)“FATE OF WATER-SOLUBLE POLYSACCHARIDES IN DRIED CHORDA FILUMA BROWN ALGA DURING WATER WASHING". Journal of Food Composition and Analysis 15: 3-9.

[7] Bequette\& France (1997). "SEAWEED AT YOUR SERVICE". UNESCO Courier50(11): 40-42.

[8] Yan, X., Nagata, T., \& Fan, X. (1998). "ANTIOXIDATIVE ACTIVITIES IN SOME COMMON SEAWEED”. Plant Foods for Human Nutrition, 52, 253-262.

[9] Jimenez-Escrig, A., Jimenez-Jimenez, I., Pulido, R., \&Saura-Calixto, F. (2001). “ANTIOXIDANT ACTIVITY OF FRESH AND PROCESSED EDIBLE SEAWEEDS". Journal of the Science of Food and Agriculture, 81, 530-534.

[10] Ismail, A., \& Hong, T. S. (2002). "ANTIOXIDANT ACTIVITY OF SELECTED COMMERCIAL SEAWEEDS". Malaysian Journal of Nutrition, 8, 167-177.

[11] Boukhari\& Sophie (1998). “ANYONE FOR ALGAE?’UNESCO Courier51(7/8): 31-32.

[12] Jiménez-Escrig A \& Sánchez-Muniz FJ (2000). "DIETARY FIBRE FROM EDIBLE SEAWEEDS: CHEMICAL STRUCTURE, PHYSICOCHEMICAL PROPERTIES AND EFFECTS ON CHOLESTEROL METABOLISM.” Nutrition Research20: 585-598.

[13] Norziah MN \&Ching YC (2000). "NUTRITIONAL COMPOSITION OF EDIBLE SEAWEEDS GRACILLARIA CHANGGI". Food Chem68: 69-76.

[14] Yuan, Y. V., Carrington, M. F. and Walsh, N. A. (2005)“EXTRACTS FROM DULSE (PALMARIA PALMATA) ARE EFFECTIVE ANTIOXIDANTS AND INHIBITORS OF CELL PROLIFERATION IN VITRO”. Food and Chemical Toxicology 43: 1073-1081.

[15] Bansemir, A., Blume, M., Schroder, S. and Lindequist, U. (2006) "SCREENING OF CULTIVATED SEAWEEDS FOR ANTIBACTERIAL ACTIVITY AGAINST FISH PATHOGENIC BACTERIA”. Aquaculture 252: 79-84. 
[Leelavathi et. al., Vol.5 (Iss.4: RAST), April, 2017]

ICV (Index Copernicus Value) 2015: 71.21

Recent Advances in Science \& Technology
ISSN- 2350-0530(O), ISSN- 2394-3629(P)

IF : 4.321 (CosmosImpactFactor), 2.532 (I2OR)

InfoBase Index IB I Factor 3.86

[16] Chew, Y. L., Lim, Y. Y., Omar, M. and Khoo, K. S. (2008)“ANTIOXIDANT ACTIVITY OF THREE EDIBLE SEAWEEDS FROM TWO AREAS IN SOUTH EAST ASIA”. LWT 41: 10671072.

[17] Siriwardhana N, Lee KW, Kim SH, Ha JW, Jeon YJ (2003) “ANTIOXIDANT ACTIVITY OF HIZIKIAFUSIFORMIS ON REACTIVE OXYGEN SPECIES SCAVENGING AND LIPID PEROXIDATION INHIBITION". Food SciTechnolInt 9:339-346.

[18] Siriwardhana N, Lee KW, Kim SH, Ha JH, Park GT, Jeon YJ (2004) "LIPID PEROXIDATION INHIBITORY EFFECTS OF HIZIKIAFUSIFORMIS METHANOLIC EXTRACT ON FISH OIL AND LINOLEIC ACID”. Food SciTechnolInt 10:65-72.

[19] Cornish ML, Garbary DJ (2010) "ANTIOXIDANTS FROM MACROALGAE: POTENTIAL APPLICATIONS IN HUMAN HEALTH AND NUTRITION”. Algae 25:000-000.

[20] Le Tutour B, Benslimane F, Gouleau MP, Gouygou JP, Saadan B, Quemeneur (1998) "ANTIOXIDANT AND PRO-OXIDANT ACTIVITIES OF BROWN ALGAE, LAMINARIADIGITATA, HIMANTHALIA ELONGATE, FUCUSVESICULOSUS, FUCUSSERRATUS AND ASCOPHYLLUMNODOSUM". J ApplPhycol 10:121-129.

[21] Zhang Q, Yu P, Li Z, Zhang H, Xu Z, Li P (2003) “ANTIOXIDANT ACTIVITIES OF SULFATED POLYSACCHARIDE FRACTIONS FROM PORPHYRAHAITANESIS”. J ApplPhycol 15:305310.

[22] Yuan H, Zhang W, Li X, Lü X, Li N, Gao X, Song J (2005) "PREPARATION AND IN VITRO ANTIOXIDANT ACTIVITY OF K-CARRAGEENAN OLIGOSACCHARIDES AND THEIR OVERSULFATED, ACETYLATED, AND PHOSPHORYLATED DERIVATES”. Carbohydr Res 340:685-690.

[23] Qi H, Zhao T, Zhang Q, Li Z, Xing R (2005) “ANTIOXIDANT ACTIVITY OF DIFFERENT MOLECULAR WEIGHT SULFATED POLYSACCHARIDES FROM ULVAPERTUSAKJELLM (CHLOROPHYTA)". J ApplPhycol 17:527-534.

[24] Yan X, Li X, Zhou C, FanX(1996) "PREVENTION OF FISH OIL RANCIDITY BY PHLOROTANNINS FROM SARGASSUM KELLMANIANUM”. J. Appl. Phycol. 8: 201-203.

[25] Yan X, Li X, Fan X, Zhou C (1997) "STUDIES ON EXTRACTION PROCEDURE AND ANTIOXIDATIVE ACTIVITY OF PHLOROTANNINS FROM SARGASSUM KJELLMANIANUM”. Chinese J. Oceanol. Limnol. 15: 42-45.

[26] Wei Y, Xu Z (2003) "STUDIES ON ANTIOXIDATIVE ACTIVITY OF HIGH MOLECULAR WEIGHT POLYPHENOLS FROM TWO KINDS OF BROWN ALGAE”. Zhongcaoyao 34: 3170319.

[27] Nakamura T, Nagayama K, Uchida K, Tanaka R (1996) “ANTIOXIDANT ACTIVITY OF PHLOROTANNINS ISOLATED FROM THE BROWN ALGA EISENIABICYCLIS”. Fish. Sci. 62: 923-926.

[28] Chkhikvishvili ID, Ranazanov ZM (2000) "PHENOLIC SUBSTANCES OF BROWN ALGAE AND THEIR ANTIOXIDANT ACTIVITY. PRIKLADNAYA BIOKHIMIYA I MIKROBIOLOGIYA" 36: 336-338.

[29] Kang HS, Chung HY, Jung JH, Son BW, Choi JS (2003a) “A NEW PHLOROTANNIN FROM THE BROWN ALGA ECKLONIA STOLONIFERA”. Chem. Pharmaceut. Bull. 51: 1012-1014.

[30] Kang HS, Chung HY, Kim JY, Son BW, Jung HA, Choi JS (2004) "INHIBITORY PHLOROTANNINS FROM THE EDIBLE BROWN ALGA ECKLONIA STOLONIFERAON TOTAL REACTIVE OXYGEN SPECIES (ROS) GENERATION”. Arch. Pharmacol. Res. 27: 194198.

[31] Rupérez P, Ahrazem O, Leal JA (2002)"POTENTIAL ANTIOXIDANT CAPACITY OF SULFATED POLYSACCHARIDES FROM THE EDIBLE MARINE BROWN SEAWEED FUCUS VESICULOSUS". J Agric Food Chem. 2002 Feb 13; 50(4):840-5.

\footnotetext{
*Corresponding author.

E-mail address: leelavathims@ gmail.com
} 